\title{
Risk appraisal for cardiovascular disease among selected young adult women in Coimbatore, India
}

\author{
S.Thilagamani and S. Uma Mageshwari \\ Department of Food Service Management and Dietetics, Avinashilingam Deemed University for Women, \\ Coimbatore- 641 043, Tamil Nadu, India \\ sthilagamani@yahoo.co.in
}

\begin{abstract}
Women's nutrition is another crosscutting issue that influences all aspects of health and well-being through adolescent into their early twenties. Young women undergo dramatic changes including physical, social, cognitive and emotional development.. Considering the issues important to the health and lifestyle of young women, this study focused on the assessment of risk for cardiovascular diseases among young women in Coimbatore, Tamil Nadu. A total of 300 women between the age group of 20 and 40 years were identified for the conduct of the study. The selected women subjects were assessed for the risk of cardiovascular diseases using a formulated risk assessment index (RAI). The selected women were appraised by categorization of the subjects into low risk, moderate risk and high risk based on the scores. These Risk Assessment Index scores were compared with lipid profile of the subjects.
\end{abstract}

Keywords: Women, diet, exercise, healthcare, obesity; risk appraisal; lipid profile, India

\section{Introduction}

Everyday we are bombarded with nutrition and health messages and a seemingly endless array of concerns about lifestyle and diet. Making smart food choices early in life and through adulthood can also help reduce the risk of certain conditions such as obesity, heart diseases, hypertension, diabetes and osteoporosis (WHO, 1995). The number of productive life lost due to cardiovascular diseases will increase in 2030 for India by $95 \%$. Globally, cardiovascular diseases are the number one cause of death and are projected to remain so. About $80 \%$ of the deaths occurred in low and middle income countries (AHA, 2008).

The modern Indian woman is subjected to excessive stress at home and work. Overworking, under-resting and a higher level of frustration at work bring about greater aggression in quality of life. The primary factor that causes cardiac problem is stress (Parikh, 2009). The effects of unhealthy diet and physical inactivity may show up individuals with raised blood pressure, blood glucose, blood lipids, overweight and obesity, which are called "Intermediate risk factors". Hence this study is an attempt to focus on the risk assessment for cardiovascular disease among selected young adult women in Coimbatore focusing working and non-working women with the following objectives: 1) Identify young adult women aged 20 to 40 years in working and non-working groups, 2) Assess risk for cardiovascular diseases among the selected young adult women and 3) Apply intervention strategies in management of cardiovascular diseases.

\section{Methodology}

The methodology adopted for the study comprises the following steps:
Selection of area and identification of women subjects

The area selected for the conduct of the study was Coimbatore in India based on the accessibility and the cooperation rendered in identification of the women subjects. The subjects selected were young adult women between the age group of 20 and 40 years covering both working and non-working sector using purposive sampling method. A total of 300 women from working and non-working sector were included for the conduct of the study. One hundred and fifty women employees from schools, colleges, insurance companies, textiles mills and information technology sectors formed the group for working women. One hundred and fifty home makers from selected residential areas of Coimbatore formed the group for non-working women.

Formulation of a risk assessment index (RAl) for cardiovascular diseases

According to Duffy et al. (2002) Nutrition components of health risk appraisal (HRA) aims to rapidly and accurately assess dietary behaviour that increase the disease risk. A risk assessment index was developed to predict the extent of risk for cardiovascular diseases among selected young adult female population. The risk assessment Index comprised the risk factors namely age, family history, physical activity, obesity, diabetes and dietary pattern. Based on the scores the young female adults were categorized as low, medium or high risk for cardiovascular diseases.

Appraisal of health risk among selected young adult women

The subjects with scores $0-50$ were categorized into low risk, $51-100$ as moderate risk and $>100$ as high risk. The sub sample of thirty six women subjects with six women from each category (low, moderate, high risk)
Research article

CIndian Society for Education and Environment (iSee)
"Women \& health in India"

http://www.indjst.org
Thilagamani \& Uma Indian J.Sci.Technol. 
were selected from working and non-working sector and were examined for lipid profile.

Nutrition and lifestyle education for the selected young adult women

Based on the food consumption and lifestyle pattern to predict and prevent the cardiovascular diseases for the selected women subjects, Nutrition and lifestyle education were planned. Counselling was given to the women subjects in form of individual and group counselling for the working and non-working women respectively using developed visual and non-visual aids.

\section{Results and discussion}

The age-wise distribution of the selected women subjects is given in Table 1. Among the three hundred women subjects selected for the study, $68 \%$ of working women and $75 \%$ of non-working women belonged to the age group 20 to 30 years. $32 \%$ of working women and $25 \%$ non-working women belong to the age group of 31 to 40 years. The study is lined with the research by Rochester (2007) who found out heart disease is the third leading cause of death for women 25 and 44 years.

The details of the familial tendency to cardiovascular diseases are discussed in Table 2. The family history of the disease showed that among the 300 women, $33 \%$ of working and $48 \%$ nonworking women had a family history of the disease. $30 \%$ of working women
Table 1. Age wise distribution of the selected working \& non-working women subjects

\begin{tabular}{|c|c|c|c|c|}
\hline \multirow{2}{*}{$\begin{array}{c}\text { Age } \\
\text { (years) }\end{array}$} & \multicolumn{2}{|c|}{$\begin{array}{c}\text { Working } \\
\text { women }\end{array}$} & \multicolumn{2}{c|}{$\begin{array}{c}\text { Non - working } \\
\text { women }\end{array}$} \\
\cline { 2 - 5 } & No. & $\%$ & No. & $\%$ \\
\hline $20-30$ & 102 & 68 & 113 & 75 \\
\hline $31-40$ & 48 & 32 & 37 & 25 \\
\hline
\end{tabular}

Table 2. Familial tendency of the selected working \& non-working women subjects

\begin{tabular}{|l|c|c|c|c|}
\hline \multirow{2}{*}{$\begin{array}{c}\text { Familial } \\
\text { Tendency* }\end{array}$} & \multicolumn{2}{c|}{$\begin{array}{c}\text { Working } \\
\text { women }\end{array}$} & $\begin{array}{c}\text { Non-working } \\
\text { women }\end{array}$ \\
\cline { 2 - 5 } & No. & $\%$ & No. & $\%$ \\
\hline No family history & 100 & 67 & 78 & 52 \\
\hline First Degree & 19 & 13 & 34 & 23 \\
\hline Second Degree & 14 & 9 & 28 & 19 \\
\hline Third degree & 17 & 12 & 10 & 6 \\
\hline
\end{tabular}

Table 3. Body mass index of the selected working \& non-working women subjects

\begin{tabular}{|l|c|c|c|c|}
\hline \multirow{2}{*}{$\begin{array}{c}\text { Body Mass } \\
\text { Index (BMI) }\end{array}$} & \multicolumn{2}{c|}{$\begin{array}{c}\text { Working } \\
\text { women }\end{array}$} & \multicolumn{2}{c|}{$\begin{array}{c}\text { Non-working } \\
\text { women }\end{array}$} \\
\cline { 2 - 5 } & No. & $\%$ & No. & $\%$ \\
\hline $\begin{array}{l}\text { Underweight } \\
(<18.5)\end{array}$ & Nil & Nil & Nil & Nil \\
\hline $\begin{array}{l}\text { Normal } \\
(18.5-24.9)\end{array}$ & 104 & 69 & 113 & 75 \\
\hline $\begin{array}{l}\text { Grade I obesity } \\
(25.0 \text { - 29.9) }\end{array}$ & 37 & 25 & 32 & 21 \\
\hline $\begin{array}{l}\text { Grade Il obesity } \\
(30.0-39.9)\end{array}$ & 9 & 6 & 5 & 3 \\
\hline
\end{tabular}

*National Cholesterol Education Program (NCEP, 2001).

Table 4. Waist hip ratio of the selected working \& non-working women subjects

\begin{tabular}{|c|c|c|c|c|}
\hline $\begin{array}{c}\text { Waist - } \\
\text { Hip Ratio } \\
(\text { WHR) }\end{array}$ & \multicolumn{2}{|c|}{$\begin{array}{c}\text { Working } \\
\text { women }\end{array}$} & \multicolumn{2}{c|}{$\begin{array}{c}\text { Non- } \\
\text { working } \\
\text { women }\end{array}$} \\
\cline { 2 - 5 } & No. & $\%$ & No. & $\%$ \\
\hline$>0.8$ & 133 & 89 & 149 & 99 \\
\hline$<0.8$ & 17 & 11 & 1 & 1 \\
\hline
\end{tabular}

women and $3 \%$ of non-working women were Grade II obese which may be critical if not taken care which will lead to other diet related diseases.

The waist hip ratio of the selected women subjects is depicted in Table 4. About $89 \%$ and $99 \%$ of the working women and non-working women had abdominal obesity, whereas $11 \%$ and $1 \%$ of working women and non-working women had normal waist hip ratio.

Dietary Pattern is discussed with the type of diet, Fat and oil intake and use of salt. Different types of diet consumed by selected women subjects are shown in the Table 5. From the table it was observed that, $8 \%$ of working women and $7 \%$ of non-working women were ova vegetarian whereas $73 \%$ of working women and $53 \%$ of non-working women were non-vegetarians. The data when statistically analyzed for chisquare, the value was (15.826) which showed a positive significance with consumption of non-vegetarian foods and risk of cardiovascular disease.

The type of fats and oils consumed by the selected women subjects is shown in the Table 6 . Ghee, a source of saturated fats was consumed by women comprising $55 \%$ of working women and $91 \%$ of working women. Sesame oil, Sunflower oil and groundnut oil was found to be more popular among the selected women. The use of vegetable oil such as have familial tendency for cardiovascular diseases was sunflower oil was consumed by the selected women with prominent among the first degree relatives over the $65 \%$ and $62 \%$ of working and non-working women second and third degree relatives. Family history on its subjects. Corn and rice bran oil were used by a few own is responsible for as much as number of selected women.

$15 \%$ of all heart attack. Family members quite often share The amount of fat used per day for the cooking is similar lifestyles and habits which may have an impact on given in the Table 7. From the selected women subjects the risk of heart disease $(\mathrm{HHC}$, 2009).

The details of body mass index are depicted in Table 3 . The Body Mass Index of the selected women subjects showed that $25 \%$ of working women and $21 \%$ of non-working women were graded as Grade I obese and $6 \%$ of working
Table 5. Type of diet by the selected working and non-working women subjects

\begin{tabular}{|l|c|c|c|c|c|}
\hline \multirow{2}{*}{ Type of diet } & \multicolumn{2}{|c|}{$\begin{array}{c}\text { Working } \\
\text { women }\end{array}$} & $\begin{array}{c}\text { Non- } \\
\text { working } \\
\text { women }\end{array}$ & \multirow{2}{*}{$\begin{array}{c}\text { Chi - } \\
\text { Square }\end{array}$} \\
\cline { 2 - 6 } & No. & $\%$ & No. & $\%$ & \\
\hline Vegetarian & 28 & 19 & 59 & 40 & \multirow{2}{*}{$15.826^{\text {s }}$} \\
\hline Ova vegetarian & 12 & 8 & 11 & 7 & \\
\hline Non vegetarian & 110 & 73 & 80 & 53 & \\
\hline & $s=$ Significantly associated \\
\hline
\end{tabular}
$59 \%$ and $53 \%$ of working women and non-working women consume three to five teaspoons of fat or oil per day. It is alarming to note that $24 \%$ of working and $20 \%$ of non-working women consume more than five teaspoons of oil per day.

The quantity of salt used for cooking by the selected women
Research article

CIndian Society for Education and Environment (iSee)
"Women \& health in India" http://www.indjst.org
Thilagamani \& Uma Indian J.Sci.Technol. 
subjects is discussed in the Table 8 . The Table 14 showed that $88 \%$ of working women and $99 \%$ of nonworking women use one tea spoon of salt per day. In statistical analysis, it was found that the chi-square value (16.3) is significantly associated which reveals that increased salt consumption, has increased risk for cardiovascular diseases. Reducing salt intake in the diet could cut the chances of developing heart diseases (Cook, 2006).

Blood pressure of the selected women subjects are discussed in the Table 9. Majority of the women, $85 \%$ from working sector and $61 \%$ from non-working women sector had normal blood pressure, whereas $12 \%$ of the working women and $27 \%$ of the non-working women had moderate blood pressure. The present study was supported with Kamath (2003) that hypertension or high blood pressure is a silent disease and is one of the risk factor of cardiovascular disease.

Life style pattern of the subjects include for the study were exercise pattern and stress pattern. The exercise pattern of the selected women subjects showed that $74 \%$ of the working women and $51 \%$ of the non-working women did not perform any exercise (Fig.1).

The stress pattern of the working and the non working women subjects are discussed in the Table 10. Occupational stress is high among working women rating $27 \%$. Familial stress is high among non-working women which are around $37 \%$ and comparatively low as far as working women is concerned which is $17 \%$. Stress was associated with higher levels of an inflammatory marked called C-Reactive protein or (CRP), which has been identified as an indicator for the later development of cardiovascular diseases (The Times of India, 2009).

The young adult working and non-working women on evaluation of the risk was categorized and examined for lipid profile. The selected subjects were assessed through risk scores (Low, moderate, high risk) and is discussed in the Table 11. From the scores calculated, it was found that $18 \%$ of working women and $27 \%$ of non-working women were in high risk for cardiovascular diseases. $75 \%$ of working women and $65 \%$ of nonworking women had moderate risk for cardiovascular diseases. Only $6 \%$ and $13 \%$ of working women and non-
Table 6. Type of fats and oils used by the selected working \& non-working women subjects

\begin{tabular}{|l|c|c|c|c|}
\hline \multirow{2}{*}{$\begin{array}{c}\text { Type of fats } \\
\text { and oils* }\end{array}$} & $\begin{array}{l}\text { Working } \\
\text { women }\end{array}$ & $\begin{array}{c}\text { Non- } \\
\text { working } \\
\text { women }\end{array}$ \\
\cline { 2 - 5 } & No. & $\%$ & No. & $\%$ \\
\hline Ghee & 83 & 55 & 136 & 91 \\
\hline Butter & 18 & 12 & 13 & 9 \\
\hline Vanaspathi & 15 & 10 & 2 & 1 \\
\hline Sesame oil & 23 & 15 & 8 & 5 \\
\hline Groundnut oil & 45 & 30 & 31 & 21 \\
\hline Sunflower oil & 97 & 65 & 93 & 62 \\
\hline Corn oil & 6 & 4 & 11 & 7 \\
\hline Rice bran oil & 18 & 12 & 20 & 13 \\
\hline \multicolumn{5}{|c}{ "Multiple response } \\
\hline
\end{tabular}

Table 7. Amount of fat and oil used per day of the selected working \& non - working women subjects

\begin{tabular}{|l|c|c|c|c|}
\hline \multirow{2}{*}{$\begin{array}{c}\text { Amount of fat } \\
\text { used /day } \\
\text { (teaspoon) }\end{array}$} & \multicolumn{2}{|c|}{$\begin{array}{l}\text { Working } \\
\text { women }\end{array}$} & \multicolumn{2}{|c|}{$\begin{array}{c}\text { Non- } \\
\text { working } \\
\text { women }\end{array}$} \\
\cline { 2 - 5 } & No. & $\%$ & No. & $\%$ \\
\hline Less than 3 & 26 & 17 & 41 & 27 \\
\hline $3-5$ & 88 & 59 & 79 & 53 \\
\hline More than 5 tsp & 36 & 24 & 30 & 20 \\
\hline
\end{tabular}

Table 8. Use of salt in cooking by the selected working and non-working women subjects

\begin{tabular}{|l|c|c|c|c|c|}
\hline \multirow{2}{*}{$\begin{array}{l}\text { Quantity of } \\
\text { salt } \\
\text { (teaspoon) }\end{array}$} & \multicolumn{2}{|c|}{$\begin{array}{c}\text { Working } \\
\text { women }\end{array}$} & \multicolumn{2}{|c|}{$\begin{array}{c}\text { Non- } \\
\text { working } \\
\text { women }\end{array}$} & $\begin{array}{c}\text { Chi } \\
\text { square }\end{array}$ \\
\cline { 2 - 5 } & No. & $\%$ & No. & $\%$ & \\
One & 132 & 88 & 148 & 99 & $16.239^{\mathrm{s}}$ \\
\hline $\begin{array}{l}\text { more than } \\
\text { one }\end{array}$ & 18 & 12 & 2 & 1 & \\
\hline \multicolumn{5}{c}{$s=$ significantly associated } \\
\hline
\end{tabular}

working women were with low risk for cardiovascular diseases. From the scores, it was observed that moderate risk has been increased due to high intake of fat and physical inactivity. When statistical analyzed, the data was found that the chi-square value (6.459) is significantly associated.

The mean lipid profile analyzed for the sub sample is discussed in the Table 12. The mean lipid profile of the selected subjects shows that moderate risk of the working and non-working women had 170.4 and $181.6 \mathrm{mg} / \mathrm{dl}$ of the total cholesterol, whereas high risk of the working and non-working women had 217.3 and $222.7 \mathrm{mg} / \mathrm{dl}$ of the total cholesterol. The correlation value for lipid profile is $0.656^{* *}$ with positive significance at $1 \%$ level. An elevated low density lipoprotein cholesterol concentration is associated with an increased risk of cardiovascular diseases. Most people realize the elevated blood cholesterol

is a major risk factor for cardiovascular diseases (Whitney \& Rolfer, 2002).

Counselling sessions were given to 150 of working women from the selected IT companies, Textile Mills, LIC employees and for 150 of non-working women in the residential areas. A total of eight sessions were planned for each group of women to make them understand the basic menu planning for family members, Type and quantity of fat and oils to be used, the form in which fibre intake would be increased, ways of preserving nutrients in the diet modifications. Stress busters such as physical exercise, meditation were also emphasized to the women subjects.

Table 9. Blood pressure of the selected working \& non-working women subjects

\begin{tabular}{|c|c|c|c|c|c|c|}
\hline \multicolumn{3}{|c|}{ Blood Pressure } & \multicolumn{2}{|c|}{$\begin{array}{l}\text { Working } \\
\text { women }\end{array}$} & \multicolumn{2}{|c|}{$\begin{array}{c}\text { Non - } \\
\text { working } \\
\text { women }\end{array}$} \\
\hline Blood pressure * & Systole & Diastole & No. & $\%$ & No. & $\%$ \\
\hline Normal & $<120$ & $<80$ & 127 & 85 & 91 & 61 \\
\hline Pre-Hypertension & $120-139$ & $80-90$ & 18 & 12 & 41 & 27 \\
\hline Stage-I Hypertension & $140-159$ & $91-99$ & 5 & 3 & 8 & 12 \\
\hline Stage - II Hypertension & $160+$ & $100+$ & Nil & Nil & Nil & $\mathrm{Nil}$ \\
\hline
\end{tabular}
lifestyle are the major causes of cardiovascular diseases.
"Women \& health in India" http://www.indjst.org
Thilagamani \& Uma Indian J.Sci.Technol. 
Table 10. Stress pattern of the selected working \& non-working women subjects

\begin{tabular}{|l|c|c|c|c|}
\hline \multirow{2}{*}{ Stress pattern } & \multicolumn{2}{|c|}{ Working women } & \multicolumn{2}{c|}{ Non-working women } \\
\cline { 2 - 5 } & No. & $\%$ & No. & $\%$ \\
\hline Relaxed \& calm & 91 & 61 & 82 & 55 \\
\hline Familial stress & 25 & 17 & 56 & 37 \\
\hline Occupational stress & 40 & 27 & 0 & 0 \\
\hline $\begin{array}{l}\text { Neighbourhood } \\
\text { stress }\end{array}$ & 8 & 5 & 20 & 13 \\
\hline $\begin{array}{l}\text { Environmental } \\
\text { stress }\end{array}$ & 9 & 6 & 4 & 3 \\
\hline
\end{tabular}

Table 11. Risk scores for the selected working and nonworking women subjects

\begin{tabular}{|l|c|c|c|c|c|}
\hline \multirow{2}{*}{ Scores } & \multicolumn{2}{|c|}{ Working women } & Non-working women & $\begin{array}{c}\text { Chi } \\
\text { square }\end{array}$ \\
\cline { 2 - 5 } & No. & $\%$ & No. & $\%$ & \\
\hline Low (<50) & 10 & 7 & 20 & 13 & \\
\hline $\begin{array}{l}\text { Moderate } \\
(51-100)\end{array}$ & 112 & 75 & 98 & 65 & \multirow{2}{*}{$6.459^{s}$} \\
\hline High ( >100) & 27 & 18 & 41 & 27 & \\
\hline \multicolumn{7}{|c|}{$s=$ significantly associated } \\
\hline
\end{tabular}

Creating awareness among the population groups especially women to adopt nutritious eating habits and healthy lifestyle practices were enlightened. Women were educated to adopt wise food choices through pamphlets, power point presentation emphasizing the inclusion of fibre rich and low fat foods. Familial and occupational stress among the working women and familial stress among the non-working women need to be stressed out through the effective stress busters namely, physical activity, exercise, meditation and positive therapy.

\section{References}

1. American Heart Association (2008) The burden of mortality attributable to diabetes. J. Amer. Medical Assoc. 28(6), 2130-2135.

2. Cook (2006) Less salt in diets, cuts heart disease risks. Br. Medical J. 5, 12.

3. Heart Health Care (2009) Hereditary heart disease risk.

4. http://www.nutralegacy.com/blog/general-healthcare/ hereditary-heart-disease.risks/

Table 12. Mean lipid profile of the selected working and non- working women subjects

\begin{tabular}{|c|c|c|c|c|c|c|}
\hline \multicolumn{2}{|c|}{$\begin{array}{l}\text { Lipid profile (Mean } \\
\text { value) }\end{array}$} & $\begin{array}{c}\text { Total } \\
\text { cholesterol } \\
(\mathrm{mg} / \mathrm{dl})\end{array}$ & $\begin{array}{c}\text { HDL } \\
\text { cholesterol } \\
\text { (mg/dl) }\end{array}$ & $\begin{array}{l}\text { LDL } \\
\text { cholesterol } \\
(\mathrm{mg} / \mathrm{dl})\end{array}$ & $\begin{array}{c}\text { VLDL } \\
\text { cholesterol } \\
(\mathrm{mg} / \mathrm{dl})\end{array}$ & $\begin{array}{c}\text { Tri- } \\
\text { glycerides } \\
(\mathrm{mg} / \mathrm{dl})\end{array}$ \\
\hline \multicolumn{2}{|c|}{ Normal Values } & $125-200$ & $30-65$ & $85-130$ & $5-40$ & Upto 160 \\
\hline \multirow{2}{*}{ 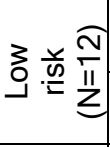 } & $\begin{array}{c}\text { Working } \\
\text { women }(\mathrm{N}=6)\end{array}$ & 155.8 & 38.7 & 87.6 & 18.3 & 96.3 \\
\hline & $\begin{array}{l}\text { Non - working } \\
\text { women }(\mathrm{N}=6)\end{array}$ & 154.1 & 39.2 & 88.8 & 19.0 & 96.9 \\
\hline \multirow{2}{*}{ 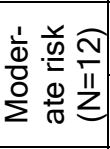 } & $\begin{array}{c}\text { Working } \\
\text { women }(\mathrm{N}=6)\end{array}$ & 170.4 & 43.1 & 102.2 & 25.3 & 118.5 \\
\hline & $\begin{array}{l}\text { Non - working } \\
\text { women }(\mathrm{N}=6)\end{array}$ & 181.6 & 45.9 & 113.2 & 28.5 & 125.9 \\
\hline \multirow{2}{*}{ 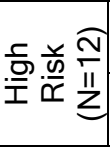 } & $\begin{array}{c}\text { Working } \\
\text { women }(\mathrm{N}=6)\end{array}$ & 217.3 & 54.7 & 132.1 & 30.9 & 155.6 \\
\hline & $\begin{array}{l}\text { Non - working } \\
\text { women }(\mathrm{N}=6)\end{array}$ & 222.7 & 53.6 & 133.8 & 33.2 & 161.2 \\
\hline
\end{tabular}

Correlation value : $0.656^{* *}$

Fiq. 1. Exercise pattern of the selected women subjects

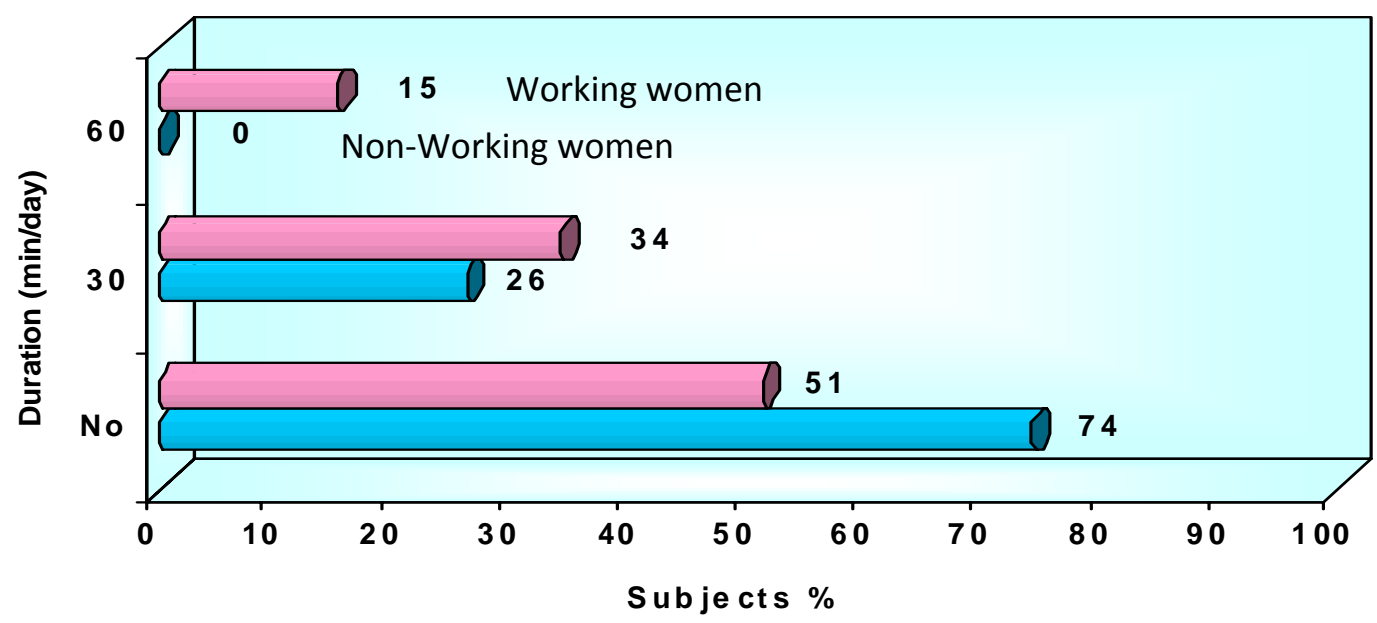

5. Parikh S (2009) Preventing and healing heart disease in women, Max health care and a health Columinst. Arch. Int Medicine. 20(1), 132.

6. Rochester (2007) All women of all ages, should take heart at Mayo clinic, Annl. Internal Medicine. 12(6), 126.

7. Whitney NE and Rolfer RS (2002) Understanding nutrition, $9^{\text {th }}$ ed., Wardsworth Thomson Learning, Austrial. pp: 602-605.

8. World Health Organization (1995) Epidemiology and prevention of cardiovascular disease in elderly people, WHO Tech. Report, 85, 3. disease, women's heart clinic
Research article

CIndian Society for Education and Environment (iSee)
"Women \& health in India" http://www.indjst.org
Thilagamani \& Uma Indian J.Sci.Technol. 